\title{
Den fremtid vi ønsker
}

Så tidligt som i 1896 forudså den svenske videnskabsmand Svante Arrhenius, at menneskets behandling af kloden ville få negativ indflydelse på samspillet mellem solen og jorden. Han opfordrede til hurtig handling. Men så uendeligt mange år efter er kloden ikke kommet nærmere sin frelse efter politiske spilfægterier i Rio i juni, hvor næsten 100 statsoverhoveder deltog. Dog glimrede sværvægtere som Barack Obama og Angela Merkel ved deres fravær, og det var sigende for resultatet: En alenlang tekst med ringe tyngde, kønne ord uden bindende forpligtelser. Aktivister rundt i verden håbede, at Rio+20 ville sætte klare mål for fødevaresikkerhed, vand og energi, men slutdokumentet havde trods sine 23.940 ord ikke meget konkret bag den pompøse titel Den fremtid, vi ønsker. Som Greenpeace direktør Daniel Mittler sagde: "Vi blev tilbudt en fælles vision om manglende handling og ødelæggelse."

Mødet markerede 20-året for den store FN-konference for udvikling og miljø i 1992. Men mens 92 var præget af håb, nye visioner og højt til det ideologiske loft efter kommunismens fald, blev Rio+20 et trist spektakel, der klart illustrerede, at trusler imod vores fælles ressourcegrundlag i dag overdøves af larmen fra bomber, redningspakker og ned- skæringer, selv om vi ser en accelereret økologisk nedbrydning og øget risiko for mangel på energi og mad.

'Grøn økonomi' var kodeordet i Rio. Det er klart, at menneskers liv forbedres, hvis miljøtrusler mindskes, men man enedes i Rio om, at hver kan vælge sin vej, selv om bindende fælles regler må til. FN udbasunerede, at Rio gav 700 evolutionære tilsagn om bæredygtig udvikling. Men slutdokumentet var laveste fællesnævner. Det kunne ikke blive mere end et kompromis, men dokumentet syntes ikke at tilfredsstille nogen. EU's klimakommissær, Connie Hedegaard, tweetede: "Ingen i det rum, der vedtog teksten, var glade".

Der er alvorlige systemfejl i det internationale udviklingsdiplomati. Rio+20 viste igen, at $\mathrm{FN}$-apparatet ikke er klædt på til udfordringerne, og at vore ledere ikke kan levere 'den fremtid, vi ønsker'. Det vil givet kun være muligt i ægte samspil med civilsamfund. FN's generalsekretær, Ban ki-Moon, opfordrede med rette civilsamfund til at skabe 'en kritisk masse' imod de mange stopklodser for en mere bæredygtig fremtid. Udenrigs sætter i dette nummer fokus på klima- og udviklingspolitikkens historie.

\section{Redaktionen}

